\title{
Literary Discourse: A Methodological Proposal for Knowledge Organization
}

\author{
João Batista Ernesto de Moraes \\ ORCID 0000-0003-4981-6521 \\ São Paulo State University / São Paulo Research Foundation, Brazil \\ Mariana da Silva Caprioli \\ ORCID 0000-0002-4206-8746 \\ São Paulo State University, Brazil \\ Larissa de Mello Lima \\ ORCID 0000-0002-5377-9535 \\ São Paulo State University, Brazil
}

\begin{abstract}
Purpose/Thesis: The complexity of subject analysis in knowledge organization is significantly increased when the material consists on imaginative literature and fiction. This situation reveals a lack of methodological studies on subject analysis of fiction literature compared with the subject analysis of scientific literature.

Approach/Methods: The methodology is the literary discourse analysis applied to two short stories by a Brazilian writer.

Results and conclusions: The short stories were analysed in order to demonstrate how this kind of analysis can be an alternative to the information representation in knowledge organization.

Originality/Value: The originality of the work lies in its choice to deal with the literary discourse analysis as a methodology for the knowledge organization.
\end{abstract}

\section{Keywords}

Discourse Analysis. Information Representation. Knowledge Organization. Literary Discourse Analysis.

Received: 5 November 2019. Reviewed: 10 November 2019. Accepted: 3 December 2019.

\section{Introduction}

According to Beghtol (1986,1994,1995,1997), García-Marco (1991), and Greimas (1973, 2010), the literary text has many particularities, and one of them is aboutness. These scholars assume that there are textual rules that contribute to the understanding of the text's meaning. The concept of aboutness, for these authors, has a textual linguistics basis under the semantic perspective. Document analysis consists of procedures which try to represent the content of a document differing from its original appearance by translation, abstracting or indexing in order to facilitate retrieval. To achieve this, it includes analytical and synthetic steps.

This paper assumes that the literary text has a particular discourse that needs to be analysed according to genre singularities. Literary discourse provides a viable methodological 
theoretical framework. In this sense, the aim of this work is to demonstrate that discourse analysis can be relevant not only to the studies which address academic-institutional documents but also to those concerned with fictional narrative texts through the literary discourse.

In order to achieve this aim, two methodological applications of the literary discourse will be demonstrated through the analysis of the short-story "Dois açucareiros" ("Two sugar bowls") by Dalton Trevisan (2004), to show how this type of work can be an alternative to the information representation in knowledge organization.

\section{Literary discourse analysis}

Maingueneau (2009, 49-50) states that literary discourse analysis (LDA) is a branch of discourse analysis (DA), since the methods and concepts are used through an adaptation, but besides this, it is a discipline conceived to study literature, and only with this purpose, whose instruments are still being built.

DA and literary discourses meet each other as the both consider the literary fact as discourse. Maingueneau $(2009,43)$ points out that this can replace "the works to the spaces that make them possible, where they are produced, evaluated, administered", as well as sending them to their condition of ennunciation which implies the consideration of the writer's state and their ways of positioning in the literary field, the roles of various genres, the relationship built from the work with its recipients, the material support and the enunciative ways of circulation. Mussalim $(2011,1456)$ adds that "all these questions are only possible to be approached when discourse is considered as [an] enunciation and as an institution", synthetizing Maingueneau's ideas.

LDA proposed by Maingueneau considers the historical and social modalities of literary communication, affirming the need to rely on the sciences of language. The author seeks to operationalize his approaches to the literary text, and thereby to highlight this position, with the following types of categories: "enunciation scene (kind of discourse; gender and scenography); discursive deixis (enunciator, co-enunciator, typography and chronography); ethos to name just the best-known categories" (Mussalim, 2011, 1457).

So, according to Maingueneau, the fundamental question for LDA:

[...] its proposal, as we said, refuses to ask 'how we go from the text to the context, or how we go from context to text', insofar as we conceive the literary text as a way of managing the context, or as a space in which we can perceive how the writer manages the constitution and legitimation of his position in the literary field - in interdiscourse, therefore (Mussalim, 2011, 1465).

In order to explain interdiscourse, Maingueneau (2009) distinguishes between universe, field and discoursive spaces. These are elements that indicate the interdiscoursive relation between discoursive formations in its discoursive functionality (Stafuzza, 2011).

In this sense, discoursive universe is a set of several discoursive formations that interact in certain circumstances, representing an unfinished and broad set that cannot be comprehended or understood globally. Stafuzza (2011) still claims that it is for this reason that the concept is of little interest to analysts, as it only defines the horizon of the domains susceptible to study, e.g. the discursive fields. Thus, discoursive fields are the sets of discoursive formations in affluence situation, delimiting each other in a specific region in the 
discursive universe. It can then be treated, from several fields, as the political, or literary, that is exactly the field explored in this work. According to Stafuzza (2011):

The discoursive formations, belonging to a certain synchrony, constitute a discoursive field of the same social formation, however, differ in the way they are filled, which makes them in polemical, alliance or opposition relation. Each one defines its identity through the mediation of this system of differences. Generally, since it is not possible to study a discursive field in its totality, subfields considered analytically productive are reclaimed, constituting the discursive spaces (Stafuzza, 2011, 62).

Discursive spaces can be defined as the discursive spaces created by discursive cuts by which the analyst separates a given space from the surrounding field, taking into account the purpose of his (their) analysis. It is necessary to have a historical knowledge to make such cuts, for it will allow the analyst to raise questions and hypotheses which can be refuted or confirmed during the research.

From the analysis of these three qualities, it can be concluded that the discourse will never be autonomous and homogeneous, always referring to other discourses and never possessing a closed identity.

Interdiscourse can be understood as an element that must be considered in every constitution of analysis, being brought to the fore in the third stage of DA by Pêcheux, with the question of discursive heterogeneity.

There is a negotiation between the heterogeneity shown in language and the constitutive heterogeneity of language in which the subject, moved by the illusion of centre, by the illusion of being the source of discourse, locates the other and delimits its place (Brandão, 2004).

It can be understood that "[...] constitutive heterogeneity occurs when there is an implicit linguistic sequence in which can be grasped by a linguistic approach stricto sensu". (Maingueneau, 2008)

The interdiscourse lies in constitutive heterogeneity, in the sense that it ties the same of discourse and its other, in an intricate relation (Maingueneau, 2008). Thus, the discourses are placed in relation to others, not existing together previously, that is, they are born in this interdiscursive network gap.

Maingueneau posits two concepts besides the interdiscourse which make it possible to to analyse the literary text as a discourse, being: positioning and interlanguage.

In order to determine who has the right to enunciate, who is positioned as a legitimate author, Maingueneau (2009) states that "each author is guided by the authority he is able to acquire, given his achievements and the trajectory it conceives from them in a given field state".

Finally, the interlanguage, which Maingueneau (2009) conceives of as the interaction of languages and registers, or the multiplicities of language that are accessible to the author, in time and space, at a certain juncture, that is, the author does not conceive his style of writing from his language, but rather his style of writing mobilizes the language to function as the sense which the author intends to construct in the work, which is language apprehended in the plurality of registers and existing languages. In wishing to write literature, the author undergoes a linguistic ritual that involves dealing with the varieties of the same language, and also with the relations of that language to languages past and contemporaneous (Mussalim, 2011).

Thus, it is possible to observe and affirm that there is relevance in studies to other spaces than the academic-institutional ones, for example, showing the importance of social practices linked to the discourses, themselves very present in the literary discourse. 
Thus, in order to prove that the LDA is a viable methodology for analysing narrative texts of fiction for the information representation, the analysis of the following short story will be conducted, which may help the information professional to understand the context of the text and the circumstances under which it was produced so that representation is adequate and retrieval more efficient.

Short story Two sugar bowls (Dois Açucareiros):

The visitors praise the porcelain set in which tea is served. The husband says:

- There are two sugar bowls in our house.

And, before the woman protests, with her hands on her waist:

- The china. And this one!

The short story begins with a description of a common domestic scene: the reception of visitors, when there is an opportunity to talk and show the best plates that the hosts own (this practice was very common in the past, where one saved "the best pieces" of table dressing and dinner ware for special occasions). Visitors praised the host's porcelain set and then exclaimed: "At home our set has two sugar bowls." After the speech, the speaker's wife apparently gets angry, and before she can say anything, the husband adds: "The china. And this one!".

Reading the dialog we can safely assume that there are at least three people involved in the conversation, where one of them is the hostess or host, also that the wife of the speaker was angry because it is not appropriate to make comparisons with possessions of people one is visiting. The husband's compliment is unusual and romantic at the same time. Of course, he does his best to be finished with the subject because of his wife's behavior, but it is an affectionate, if slightly ironic, compliment.

Calling the wife "sugar bowl" can be read as complimentary because a sugar bowl, literally speaking, is full of sugar, so the husband would be using the metaphor to say that his wife is a person full of sweetness. But it can also be ironic, since the phrase was said after the wife became apparently angry with her husband, so he could be referring to her as a sweet person only ironically, since he appears to be angry and a bitter person. When he uses the expression "And this one", the second alternative seems more likely, because it is an expression that is not very polite and intends to serve as an example of what he says.

The ironic use of metaphor is once again noted in the short story of Trevisan. The metaphor can be understood as a linguistic artifice capable transferring meaning from one term to another, by means an implicit comparison.

This analysis is only speculative on the part of the analyst, which aims to observe the context and ideas which may be hidden behind the written discourse.

It is at this stage of the analysis that we can see if the text counts on the force of ideas of the literary discourse, making it then a legitimate literary discourse, as in Table 1.

It is observed that the once he picks up other discourses, before and after this one, the author uses a previously constructed element, expressing in a stronger way as relative to the other tales, in which the subject here the enunciator author, is inserted and dominates the conjuncture. It also used the element of humour.

Short Story What a life (Que Vidinha):

Mother and daughter on a vacation at the beach. In the shade of a tree, sitting on the grass, two scoops of ice cream for each.

- What a life more or less ours, huh, mother! 
Tab. 1. Force ideas from Literary Discourse

\begin{tabular}{|c|c|}
\hline $\begin{array}{l}\text { Force ideas } \\
\text { from literary discourse }\end{array}$ & Discourse legitimation \\
\hline $\begin{array}{l}\text { Discourse supposes } \\
\text { a transfrastic } \\
\text { organization }\end{array}$ & $\begin{array}{l}\text { In the short story it can be affirmed that the literary discourse is } \\
\text { legitimate, because it is submitted to the rules of organization that } \\
\text { prevail in the short stories }\end{array}$ \\
\hline $\begin{array}{l}\text { Discourse is a form } \\
\text { of action }\end{array}$ & $\begin{array}{l}\text { It interacts through the language (dialog between the characters) } \\
\text { with the reader, mobilizing this to correspond to the author's will in } \\
\text { the act of spoken language }\end{array}$ \\
\hline Discourse is interactive & $\begin{array}{l}\text { Exchange of relations of language between the real interlocutors } \\
\text { (reader) and fictitious (characters) linked to principle of cooperation }\end{array}$ \\
\hline Discourse is oriented & $\begin{array}{l}\text { It develops in time, constituted in function of being understood, } \\
\text { having its statements strongly controlled and having short stories } \\
\text { characteristics with puns and meaning for public determined by the } \\
\text { speaker (young adults / adults) }\end{array}$ \\
\hline $\begin{array}{l}\text { Discourse } \\
\text { is contextualized }\end{array}$ & $\begin{array}{l}\text { It is contextualized, because it is a short story with a quotidian } \\
\text { construction, appearing almost as if the author himself had gone } \\
\text { through it. However, it again uses irony, but now with the use of the } \\
\text { metaphor. Besides, it shows its ideological formation }\end{array}$ \\
\hline $\begin{array}{l}\text { Discourse is assumed } \\
\text { by a subject }\end{array}$ & $\begin{array}{l}\text { It is assumed not by only one, but by two subjects, with implicit } \\
\text { deitic elements which collaborate to observe the dialogs of short } \\
\text { story, an element of extreme importance in literary discourses, since } \\
\text { it shows the subject assuming the enunciation and inscribing itself in } \\
\text { the discourse, with linguistic elements that put in evidence time and } \\
\text { place, even if implicit, and indicate the participants in an situation of } \\
\text { statement involving two speakers }\end{array}$ \\
\hline $\begin{array}{l}\text { Discourse is ruled } \\
\text { by norms }\end{array}$ & $\begin{array}{l}\text { It is ruled by specific norms for the type of gender treated, legitima- } \\
\text { ting the formation of a unit with speech exercise, these norms are: } \\
\text { Short Story Structure: } \\
\text { Action: Density and intensity, predominating with the intensity; } \\
\text { Time: Chronological (metaphysical) - implicit; } \\
\text { Space: Home of the hosts who receive visits; } \\
\text { Characters: Flat characters; } \\
\text { Point of view: The third person, the narrator tells the story as an } \\
\text { observer; } \\
\text { Narrative Resources: Dialogs, Description and Narration; } \\
\text { Short story classification: A characteristic short story }\end{array}$ \\
\hline $\begin{array}{l}\text { Discourse is considered } \\
\text { within the scope } \\
\text { of interdiscourse }\end{array}$ & $\begin{array}{l}\text { It has its role assumed inside another discourse, since it is a story } \\
\text { that is part of a book, where the author expresses several ideas, this } \\
\text { being only one of them, possessing a specific tone of genre what is } \\
\text { inserted in the literature discursive activity }\end{array}$ \\
\hline
\end{tabular}

The short story consists of a single utterance [and a narrative description; maybe 'contains only one utterance'], but one that implies two people who talk, being identified already at the beginning of "mother" and "little girl". It begins with the description of the 
scenario into which the characters are inserted. The author points out that the characters find themselves vacationing on the beach, sitting on the grass, in the shade of a tree and tasting ice cream. The only utterance in the text is spoken by the character identified as the daughter: "What a life more or less ours, huh, mother!".

The author can describe the scenario in a sparse, but clear way and this allows the reader to imagine how the action is happening. The final sentence is ironic on the part of the daughter, because obviously the life of the two characters, at the time of the story, is in great conditions. They are on the beach, tasting ice cream and there is nothing to imply that they are unhappy, and for that reason the phrase is considered ironic, since the daughter affirms that both of their lives are "more or less". The term "more or less" does not have a formal definition, but can be generally understood, as something aimed at giving an estimate, approximate result, a doubt, a colloquial phrase.

Here, it can be understood as a negative definition of the characters' life, akin to a phrase "what a bad life".

It can also be observed that the discourse is contextualized, since currently, especially in social networks where people expose their lives constantly, it is not uncommon to find phrases such as this in a photo caption or a status update. This construction is accomplished by polysemy, where a word or, as here, a locution can contain several meanings, since, if taken literally, the daughter's statement can be understood as a claim to a life that is not good. It is at this point in the analysis that we observe that the text has the strengths of the literary discourse, making it a legitimate literary discourse, as in Table 2.

Tab. 2. Force ideas from literary discourse

\begin{tabular}{|c|c|}
\hline $\begin{array}{c}\text { Force ideas } \\
\text { from literary discourse }\end{array}$ & Discourse legitimation \\
\hline 1 & 2 \\
\hline $\begin{array}{l}\text { Discourse supposes } \\
\text { a transfrastic } \\
\text { organization }\end{array}$ & $\begin{array}{l}\text { In the short story } 2 \text {, it too can be affirmed that the literary discourse } \\
\text { is legitimate, because it is subject to the rules of organization that } \\
\text { prevail in the short stories }\end{array}$ \\
\hline $\begin{array}{l}\text { Discourse is a form } \\
\text { of action }\end{array}$ & $\begin{array}{l}\text { It interacts through the language (dialog between the characters) } \\
\text { with the reader, mobilizing it to correspond to the author will in the } \\
\text { act of spoken language }\end{array}$ \\
\hline Discourse is interactive & $\begin{array}{l}\text { Exchange of relations of language between the real interlocutors } \\
\text { (reader) and fictitious (characters) linked to principle of coopera- } \\
\text { tion }\end{array}$ \\
\hline Discourse is oriented & $\begin{array}{l}\text { It develops in time, constituted in function of being understood, } \\
\text { having its statements strongly controlled and having short stories } \\
\text { characteristics with puns and meaning for public determined by the } \\
\text { speaker (young adults / adults) }\end{array}$ \\
\hline $\begin{array}{l}\text { Discourse } \\
\text { is contextualized }\end{array}$ & $\begin{array}{l}\text { It is contextualized, because it is a short story with an everyday con- } \\
\text { struction, appearing almost as if the author himself had gone thro- } \\
\text { ugh it. However, uses again the irony, but now with the use of the } \\
\text { language figure metaphor. Besides, shows its ideological formation }\end{array}$ \\
\hline
\end{tabular}




\begin{tabular}{|l|l|}
\hline \multicolumn{1}{|c|}{1} & \multicolumn{1}{|c|}{2} \\
\hline $\begin{array}{l}\text { Discourse is assumed } \\
\text { by a subject }\end{array}$ & $\begin{array}{l}\text { It is assumed not by only one, but by two subjects, with the implicit } \\
\text { deitic elements which collaborate to observe the dialogs of short } \\
\text { story, an element of extreme importance in literary discourses, } \\
\text { since it shows the subject assuming the enunciation and inscribing } \\
\text { itself in the discourse, with linguistic elements that put in evidence } \\
\text { time and place, even if implicit, and indicate the participants in an } \\
\text { situation of statement involving two speakers }\end{array}$ \\
\hline $\begin{array}{l}\text { Discourse is ruled } \\
\text { by norms }\end{array}$ & $\begin{array}{l}\text { It is ruled by specific norms for the type of gender treated, legitima- } \\
\text { ting the formation of a unit with speech exercise, these norms are: } \\
\text { Story Structure: } \\
\text { Action: Density and intensity, predominating with the intensity; } \\
\text { Time: Chronological (metaphysical) - implicit; } \\
\text { Space: A beach, with grass, and trees that provide shade; } \\
\text { Characters: Flat characters; } \\
\text { Point of view: Third person, the narrator tells the story as an obse- } \\
\text { rver; } \\
\text { Narrative Resources: Dialogs, Description and Narration; } \\
\text { Short story classification: Character short story }\end{array}$ \\
\hline $\begin{array}{l}\text { Discourse is considered } \\
\text { within the scope } \\
\text { of interdiscourse }\end{array}$ & $\begin{array}{l}\text { It has its role assumed inside another discourse, since it is a story } \\
\text { that is part of a book, where the author expresses several ideas, be- } \\
\text { ing this only one of them, possessing a specific tone of genre what is } \\
\text { inserted in the literature discursive activity }\end{array}$ \\
\hline
\end{tabular}

Finally, it is possible to draw some conclusions. Firstly, it is difficult to find studies dealing with discourse analysis focused on narrative texts. This barrier becomes apparent, and is overcome in this work, which opens a new direction for further research. This fact shows how the methodology is malleable and interesting for other contexts. Discourse analysis is extremely complex and engaging and can be applied in many fields.

One can also observe how the representation of narrative works of fiction makes works "trapped" in information units, and by "trapped" we mean that they are represented, but often are not found efficiently, or not at all. Literary texts have a large space in libraries, mainly public and children's libraries, and have the right to be better represented so that they might be better retrieved and used.

\section{Discussion}

It can be noted that the author Dalton Trevisan used previously constructed elements in order to resume other discourses, previous and subsequent to the uttered, expressing striking ideological formations, wherein the subject who says, here the author enunciator is inserted and dominates the conjuncture. He also used the element of humor in these ideological formations, emphasizing even more the flexibility of the literary discourse analysis as a methodology for the knowledge organization.

In closing lines, working with the discourse analysis focused on literature provided a great opportunity to see how one can extract information from where it is not explicit, 
from a singular, or many author/s, just by observing the form in which he wrote his texts and the context in which he wrote.

\title{
Acknowledgments
}

This research was sponsored by São Paulo Research Foundation (Fapesp) and by National Council for Scientific and Technological Development (CNPq) to whom we are grateful for the support.

\section{References}

Beghtol, C. (1986). Bibliographic Classification Theory and Text Linguistics: Aboutness Analysis, Intertextuality and the Cognitive Act of Classifying Documents. Journal of Documentation, 42(2), 84-113.

Beghtol, C. (1994). The Classification of Fiction: The Development of a System Based on Theoretical Principles. Metuhen, NJ: Scarecrow Press.

Beghtol, C. (1995). Domain Analysis, Literary Warrant, and Consensus: The Case of Fiction Studies. Journal of the American Society for Information Science, 46(1), 30-44.

Beghtol, C. (1997). Stories: Applications of Narrative Discourse Analysis to Issues in Information Storage and Retrieval. Knowledge Organization, 24(2), 64-71.

Brandão, H. H. N. (2004). Introdução à análise do discurso. Campinas, SP: Editora da UNICAMP.

García-Marco, L.F., García-Marco, F.J. (199l). Resumen de documentos literarios narrativos: algunas propuestas metodológicas. Organización del Conocimiento en Sistemas de Información y Documentación, 2, 73-85.

Greimas, A.J. (1973). Semântica estrutural. São Paulo: Cultrix.

Greimas, A.J.; Courtés, J. (2010). Dicionário de semiótica. São Paulo: Contexto.

Maingueneau, D. (2009). Discurso Literário. Editora Contexto: São Paulo.

Maingueneau, D. (2008). Gênese dos discursos. São Paulo: Parábolas Editorial.

Mussalim, F. (2011). Análise do discurso literário: campo discursivo e posicionamento na interlíngua. Anais do VII Congresso Internacional da Abralin, n.1.

Stafuzza, G. (2011). Análise do Discurso Literário: das vozes de Homero em Joyce. Brasil: Appris, Trevisan, D. (2004) Vozes do retrato - Quinze histórias de mentiras e verdades. São Paulo: Ática.

\section{Dyskurs literacki: propozycja metodologiczna dla organizacji wiedzy}

\begin{abstract}
Abstrakt
Cel/Teza: Analiza treści dokumentu w ujęciu organizacji wiedzy jest procesem złożonym, szczególnie w sytuacji, w której przedmiotem opisu jest literatura piękna. Problemem jest tutaj jednak brak badań o charakterze metodologicznym związanych z analizą treści literatury pięknej.

Koncepcja/Metody badań: Metodologia badań zakłada wykorzystanie analizy dyskursu literackiego w odniesieniu do dwóch brazylijskich opowiadań.

Wyniki i wnioski: Zastosowana analiza dyskursu miała na celu pokazanie alternatywnego podejścia do reprezentacji informacji w ujęciu organizacji wiedzy.
\end{abstract}


Oryginalność/Wartość poznawcza: Oryginalność badań polega na wykorzystaniu analizy dyskursu literackiego jako metody w obszarze organizacji wiedzy.

\section{Słowa kluczowe}

Analiza dyskursu. Analiza dyskursu literackiego. Organizacja wiedzy. Reprezentacja informacji.

Professor JOÃO BATISTA ERNESTO DE MORAES holds a graduation in Letters from São Paulo State University - Unesp (1984); Master in Literature from São Paulo State University - Unesp (1990); Doctorate in Literature from São Paulo State University - Unesp (1999). He is currently an Associate Professor at São Paulo State University - Unesp, and researcher from the National Council for Scientific and Technological Development $(\mathrm{CNPq})$. Has experience in Information Science, focusing on Documental Analysis of Fiction, Discourse Analysis and Information Science, and Literary Discourse Analysis. Selected publications: JBE de Moraes, LM Lima, D. Martínez-Avila, M. da Silva Caprioli. (2017). Foucault: power, vigilance, discipline and punishment an analysis of the concept of panoptic in fiction narrative. Informação \& Informação, 22, 297-319; JBE de Moraes, M. da Silva Caprioli. (2017). Literary Discourse Analysis for information representation: ethical bias. Informação \& Sociedade, 27; JBE de Moraes, M. da Silva Caprioli. (2016). The Discourse path of Information Science in Brazil: analysis of articles from area journals in the 1990s. Brazilian Journal of Information Science, 10, 73-81.

Contact to the Author:

joao.batista@unesp.br

Information Science Department

Faculty of Philosophy and Sciences

São Paulo State University - Unesp

Rua Iara Clube, 85

Marília - SP

Brazil

MARIANA DA SILVA CAPRIOLI, holds a bachelor's degree in Library Science from São Paulo State University - Unesp; Master's in information science from São Paulo State University - Unesp, is currently a PhD student in Information Science from São Paulo State University - Unesp. The object of study of her thesis is Machado de Assis and his speech, life and work. Her research topics of interest are: Information Science Epistemology, Discourse Analysis as a methodology in Information Science; Research Methodologies in Information Science, Literary Discourse Analysis, Document Analysis, Indexing; Linguistics and Information Science. Is also a librarian at the municipal library of Marília "João Mesquita Valença" where she works with projects related to children and adolescents, as well as technical processing of materials. Selected publications: Foucault: power, vigilance, discipline and punishment an analysis of the concept of panoptic in fiction narrative. Informação \& Informação, 22, 297-319; JBE de Moraes, M. da Silva Caprioli. (2017). Literary Discourse Analysis for information representation: ethical bias. Informação \& Sociedade, 27; JBE de Moraes, M. da Silva Caprioli. (2016). The Discourse path of Information Science in Brazil: analysis of articles from area journals in the 1990s. Brazilian Journal of Information Science, 10, 73-81.

LARISSA DE MELLO LIMA, holds a bachelor's degree in Library Science São Paulo State University - Unesp; Master's in Information Science from São Paulo State University - Unesp; and is currently a PhD student in Information Science from São Paulo State University - Unesp and is a volunteer in cultural activities at Marilia Libraries, talking about the life and work of Brazilian writer Clarice Lispector that is the object of study of her thesis. His research topics of interest are: Information Science Epistemology, Discourse Analysis as a methodology in Information Science; Research Methodologies in Information Science, Literary Discourse Analysis, Document Analysis, Indexing; Linguistics and Information Science. Selected publications: L. de Mello Lima, P. Marin-Arraiza. (2019). Discourse Analysis of the French Matrix as a Technical Center in Information Science Research. Investigacion Bibliotecologica, 33, 67; JBE de Moraes; L. de Mello Lima. (2017). The legitimation of the theoretical-methodological elements of discourse analysis in Brazilian Information Science: an input of content analysis. Brazilian Journal of Information science, 11, 88-95. 